\title{
PERCEPTION OF EUROPEAN TOURIST TOWARD BALI AS TOURISM DESTINATION
}

\author{
I Gusti Bagus Rai Utama \\ Hospitality Management Department, Dhyana Pura University, Bali 80361, Indonesia \\ Email: igustibagusraiutama@gmail.com
}

\begin{abstract}
This research aimed to determine main attractor factors of Bali tourism and predominantly factors that determine the European travel to Bali. It was designed by using research survey that involving 167 European tourist selected purposively. Confirmatory factor analysis techniques were used to analyse a wide range of variables Balinese charm. The results showed the main attractor factors of Bali tourism are (1) Immigration, security of destination, and travel agencies, (2) The prices, the accommodation, food and transportation, (3) The history, culture, and natural beauty. While the most dominant factor in determining European tourists travelled to Bali were immigration, security of destination, and travel agencies. The findings also indicated that the images of Bali tourism are the destination's history, culture, and nature. These three variables were in accordance with expectations of European tourists who have been known as travellers who like the interested on history, culture, and the beauty of the scenery.
\end{abstract}

Keywords: Image, history, culture, scenery, tourist, European.

\section{Introduction}

Recently, many people assume that the culture of Bali is the main attraction of tourism Bali has undergone a change and even considered has been degraded. In the similar side, natural resources of Bali also considered to have been degraded over the development of tourism in Bali. However, the fact those tourist arrivals of European tourists are quite sensitive to both issues that actually increased to 135,215 people during a two month period from January to February 2016. The increasing numbers are accounted for 18.61 percent or 726,625 people of all foreign tourists who travelled to Bali. The arrivals of European tourists who travel to Bali every month are incresed by 67,026 people during January, to 68,219 people in February 2016 (Sutika, 2016). Although the economic conditions of Europe have not been too favourable, but tourists from that region remained increasing consistently. Increasing the number of European tourist is considered that Bali Island has power to attract them to visit Bali.

Indeed, tourism market share can be divided by various categories, such categories of origin, age, occupation, education, etcetera which can be observed empirically. This study was conducted to confirm the existences of important tourism attraction variables to determine which factors are as the main attraction of Bali from perspective of European tourist who visited Bali. This study is confirmatory analysis to determine the existence of the tourist attraction of Bali Island as a tourism destination from perspective of European tourist. The research problems are defined in this stu- dy: (1) what factors are the main attraction of Bali destination from perspective European tourist? (2) Which factors determine the dominant European tourist to visit Bali?

Currently, there are still a lot debating on differing views on the components about the image of the destination. For example, Crompton, Fakeye and Lue (1992) assumed that the destination image consists of only cognitive component, whereas perceptual or cognitive evaluation only refers to an individual's knowledge and belief in an object perceived or evaluated. Mazursky and Jacoby (1986) considered that consumers build an overall image based on the evaluation of various attributes that consist of goods and services. Likewise, Gartner (1993) stated that the perception of tourists to various destinations attributes will interact in shaping the image of the overall image. However, Keown, Jacobs and Worthley (1984) had been tested by the empirical fact that there is a relationship between cognitive attributes and overall image, and concluded that the overall impression is dependent upon the attributes of destinations based on the perception of tourists individually.

Milman and Pizam (1995) stated that cognitive offers three components that determine the image of destinations, namely: attractions, the hosts' behavior and attitude, and the environment such as climate, facilities, and etcetera. Meanwhile, Goeldner, Ritchie and McIntosh (1999) identified that cognitively, destination image consists of a psychological component rating, uniqueness, and destination attributes holistically. Furthermore, Chi (2005) had conducted research and classify the nine attributes that affect the 
overall image of the destination, namely (1) the attributes of nature, (2) the opportunity rating for fun and recreation, (3) the natural environment, (4) public facilities, (5) the culture, history, and art, (6) the social environment, (7) the tourism infrastructure, (8) economic and political factors, and (9) the atmosphere destinations. In order to maintain and increase the growth of the market segment of European tourists, the necessary creativity and innovation in managing the business and product packaging to reach the preferences of tourists, especially European tourists. The behavior of European tourists can be seen from their lifestyle based on the dimensions of cultural differences, the dimensions of self attitude and lifestyle dimensions simultaneously.

This study is the confirmation of the existences of the Bali tourism attraction with the participation of European tourist. This research is expected to result in significant and meaningful information for sustainability of Bali tourism destination. In this context it becomes important to investigate is the attraction and motivation European tourist to visit Bali. The image and destination attractions are a perception formed from a variety of information received by tourists. Each tourism destination has particular attraction and image that contains beliefs, impressions, and perceptions of a destination. The image formed is a combination of various factors that exist in destinations such as the weather, landscapes, security, health and sanitation, hospitality, and others (Coban, 2012; Jamaludin, Johari, Aziz, Kayat, \& Yusof, 2012). Attractiveness and image of the destination is always experiencing the dynamics over the development technology, communication and information should be more used by media, audio, visual and so research on the image of destinations should be done so that these dynamics can be determined.

\section{Research Method}

The quantitative approaches are used in this study to find attraction destination variables from perspective of European tourist (Esichaikul, 2012). The application of theories and concepts related destinations to formulate the strategy so that the number of European tourists who visit Bali can be increased.

This research was conducted in the province of Bali in period of April to August 2016, and was designed using research survey that involving 167 European tourist as respondents. The respondents were selected purposively when they are on vacation in Bali. Confirmatory factor analysis techniques are used to analyse a wide range of destination attractions factors that expected to produce a couple of dominant factor determining the European tourists (Hair, Black, Babin, \& Anderson, 2006).

Factor analysis is done through the various phases that define a number of variables corresponding to research problems, then determine the adequay of the respondent, and then factor analysis with rotation of factors, grouping factor, then the naming factor appropriate representation of the variable constituent, and the last stage is determine factor model accuracy (Santoso, 2005).

\section{Result and Discussion}

\section{Respondent Profile}

Based on their gender groups of 167 respondents who participated in this study, illustrated that male respondents are more dominant about 58.1 percent compared with about 41.9 percent of the female respondents as seen on Table 1 .

Table 1

Respondents Profile by Gender

\begin{tabular}{ccc}
\hline Gender & $\begin{array}{c}\text { Number of } \\
\text { Respondent }\end{array}$ & Percentage \\
\hline Male & 97 & 58.1 \\
Female & 70 & 41.9 \\
Total & 167 & 100 \\
\hline
\end{tabular}

However, based on the frequency of their visiting Bali from 167 respondents are illustrated that the dominant respondents had more than twice travelled to Bali which is about 46.7 percent, 33.5 percent for the first time visit, and 19.8 percent as second visit time as seen on Table 2.

Table 2

The Frequency of Their Visiting Bali

\begin{tabular}{ccc}
\hline Visiting Bali & $\begin{array}{c}\text { Number of } \\
\text { Respondent }\end{array}$ & Percentage \\
\hline Second visit & 33 & 19.8 \\
More than twice & 78 & 46.7 \\
First time visit & 56 & 33.5 \\
Total & 167 & 100 \\
\hline
\end{tabular}

Based on their nationality of 167 respondents, reflected that respondents predominantly from the Dutch about 24.6 percent, and German about 16.2 percent, French about 9.6 percent, British 9 percent and the of Italian, the Swiss, Russian, Sweden, Belgian, Spaniard, Finn, Irish, Dane, the Norway, and others as seen on Table 3. 
Table 3

Nationality of Respondents

\begin{tabular}{lcc}
\hline \multicolumn{1}{c}{ Nationality } & $\begin{array}{c}\text { Number of } \\
\text { Respondent }\end{array}$ & Percentage \\
\hline Dutch & 41 & 24.6 \\
German & 27 & 16.2 \\
French & 16 & 9.6 \\
British & 15 & 9.0 \\
Italian & 13 & 7.8 \\
The Swiss & 13 & 7.8 \\
Russian & 8 & 4.8 \\
Swede & 8 & 4.8 \\
Belgian & 7 & 4.2 \\
Spaniard & 4 & 2.4 \\
Finn & 3 & 1.8 \\
Irish & 3 & 1.8 \\
Dane & 2 & 1.2 \\
Norwegian & 2 & 1.2 \\
Others & 5 & 3.0 \\
Total & 167 & 100 \\
\hline
\end{tabular}

Attractiveness of Bali According European Tourists

The finding of a survey of 167 respondents as seen as Table 4 were analysed using statistic descripttive analysis based on the mean for the destination attractions of Bali, may indicate that the variable of the beauty of the scenery, Bali-ness culture, and history of Bali are ranked on the top ranking means and they have a very strong attractiveness to attract European tourist to visit Bali.

Table 4

Attractiveness of Bali According European Tourists

\begin{tabular}{|c|c|c|c|}
\hline Variables & Mean & Remarks & Rank \\
\hline The beauty of the scenery & 4.4431 & Very good & 1 \\
\hline Balinese Culture & 4.3413 & Very good & 2 \\
\hline History of Bali & 4.2754 & Very good & 3 \\
\hline Variations Travel Attractions & 3.9401 & Good & 4 \\
\hline Events and Festivals & 3.9222 & Good & 5 \\
\hline The Varian of Culinary & 3.8503 & Good & 6 \\
\hline Prices of Goods and Services & 3.6946 & Good & 7 \\
\hline Distance from Origin Country & 3.6407 & Good & 8 \\
\hline Facilities and Services Hotel & 3.5389 & Good & 9 \\
\hline Transportation & 3.3952 & Enough & 10 \\
\hline $\begin{array}{l}\text { Quality of Service Travel } \\
\text { Agent }\end{array}$ & 3.3772 & Enough & 11 \\
\hline $\begin{array}{l}\text { Facilities and Services } \\
\text { Wellness }\end{array}$ & 3.3353 & Enough & 12 \\
\hline Security on Destinations & 3.2874 & Enough & 13 \\
\hline Quality Services Guides & 3.2395 & Enough & 14 \\
\hline Immigration services & 3.0599 & Enough & 15 \\
\hline
\end{tabular}

While the variables that have the average perceptions are the security of destination, service guides, and immigration services. All three of these variables indicate that these are still not fully convinced they travelled to Bali from perspective of European tourist. However, of the 15 variables were analysed descriptively, show that the variation of attractions, events and festivals, culinary, prices of goods and services, the distance from the country of origin, the facilities and the hotel services, transportation, quality of services of travel agent, as well as facilities and wellness services are evaluated enough to convince respondents travelled to Bali.

\section{Attractiveness Factors Analysis of Bali Destinations According European Tourist}

Determine the variables that are considered eligible to be included in subsequent factor analyses, by imposing a number of tests on all variables, and remove variables that proved unfeasible. In this case the method KMO and Bartlett Test of Sphericity, measurement MSA (Measure of Sampling Adequacy) as well as testing with Anti Image Matrices. The test results Table 5 shows that the value of KaiserMeyer-Olkin Measure of Sampling Adequacy is about 0.840 which means the number of respondents statistically is adequate for factor analysis.

Table 5

KMO and Bartlett's Test

\begin{tabular}{llr}
\hline Kaiser-Meyer-Olkin Measure of Sampling & 0.840 \\
Adequacy. & & 1153,343 \\
Bartlett's Test of & Approx. Chi-Square & 105 \\
Sphericity & Df & 0.000 \\
& Sig. \\
\hline
\end{tabular}

The process of factoring is to do the extraction of the set of variables which are to determine one or more factors. The method used to perform the extraction process is the Principal Component Analysis. Table 6 shows that the results of the analysis that determined by the three components or factors with eigenvalues initial cumulative percentage about 59.838 percent.

The next process is the process of rotation to determine factors. The results of the rotated analysis of Component Matrix as seen on Table 7 shows that the variable the beauty of the scenery, Balinese Culture, and History of Bali are formed as Factor 3. While the variable prices of goods and services, events and festivals, variations tourist attraction, transportation, distance from the country of origin, variety culina- 
ry, hotel facilities and services are formed as Factor 2 , and variable of facilities and wellness services, immigration services, destination safety, quality of service travel agent, tour guide service are formed into Factor 1.

Table 6

Total Variance Explained

\begin{tabular}{cccc}
\hline \multirow{2}{*}{ Component } & \multicolumn{3}{c}{ Initial Eigenvalues } \\
\cline { 2 - 4 } & Total & \% of Variance & $\begin{array}{c}\text { Cumulative } \\
\text { \% }\end{array}$ \\
\hline 1 & 5.765 & 38.433 & 38.433 \\
2 & 1.989 & 13.258 & 51.691 \\
3 & 1.222 & 8.147 & 59.838 \\
\hline
\end{tabular}

\section{Extraction Method: Principal Component Analysis}

Table 7

Rotated Component Matrix

\begin{tabular}{lccc}
\hline \multirow{2}{*}{\multicolumn{1}{c}{ Variable }} & \multicolumn{3}{c}{ Component } \\
\cline { 2 - 4 } & $\mathbf{1}$ & $\mathbf{2}$ & $\mathbf{3}$ \\
\hline The beauty of the scenery & 0.065 & 0.314 & $\mathbf{0 . 8 1 3}$ \\
Balinese Culture & 0.141 & 0.115 & $\mathbf{0 . 8 9 0}$ \\
History of Bali & 0.053 & 0.062 & $\mathbf{0 . 7 5 8}$ \\
Variations Travel Attractions & 0.270 & $\mathbf{0 . 6 3 5}$ & -0.034 \\
Events and Festivals & 0.164 & $\mathbf{0 . 5 0 6}$ & 0.497 \\
The Varian of Culinary & 0.091 & $\mathbf{0 . 6 8 9}$ & 0.111 \\
Prices of Goods and Services & 0.308 & $\mathbf{0 . 6 4 8}$ & 0.227 \\
Distance from Origin Country & 0.329 & $\mathbf{0 . 5 6 3}$ & 0.212 \\
Facilities and Services Hotel & -0.007 & $\mathbf{0 . 6 1 6}$ & 0.206 \\
Transportation & 0.361 & $\mathbf{0 . 6 1 2}$ & 0.130 \\
Quality of Service Travel Agent & $\mathbf{0 . 5 4 9}$ & 0.296 & 0.381 \\
Facilities and Services Wellness & $\mathbf{0 . 8 1 5}$ & 0.155 & 0.195 \\
Security on Destinations & $\mathbf{0 . 7 8 8}$ & 0.148 & 0.084 \\
Quality Services Guides & $\mathbf{0 . 8 4 9}$ & 0.145 & -0.034 \\
Immigration services & $\mathbf{0 . 7 2 1}$ & 0.386 & 0.047 \\
\hline
\end{tabular}

Extraction Method: Principal Component Analysis.

Rotation Method: Varimax with Kaiser Normalization.

Rotation converged in five iterations.

Naming each of the factors that have been determined, it can be started from a factor that has the greatest eigenvalues to the smallest as sees on Table 8.

Test the accuracy of the model determine that "Residuals are computed correlations between observed and Reproduced are 53 (50.0\%) as non-redundant residuals with absolute values greater than 0:05". The accuracy test means that the model has been formed trustworthy by $50 \%$.

\section{The Main Factors Determine European Tourist Travel to Bali.}

Factor analysis ultimately determines that there are three factors as the main attraction for European tourists to visit Bali which can be explained as follows: 1) The first factor is the factor of immigration, security of destinations, and travel agencies services, with an initial strength of eigenvalues percentage of variance about $38.433 \%$. The first factor consists of facilities and wellness services, immigration services, security destinations, travel agent service quality, and service guides. 2) The second factor is the prices, accommodations, food and beverage, and transportation, with the initial strength eigenvalues percentage of variance about $13.258 \%$. The second factor is composed of the prices of goods and services, events and festivals, variations tourist attraction, transportation, distance from the country of origin, culinary variety, and the facilities and hotel services. 3) The third factor is the factor of history, culture, and natural beauty with a initial strength of eigenvalues percentage of variance about $8.147 \%$. The third factor is composed of History of Bali, Baliness Culture and the beauty of the scenery of Bali.

Table 8

Naming Factors

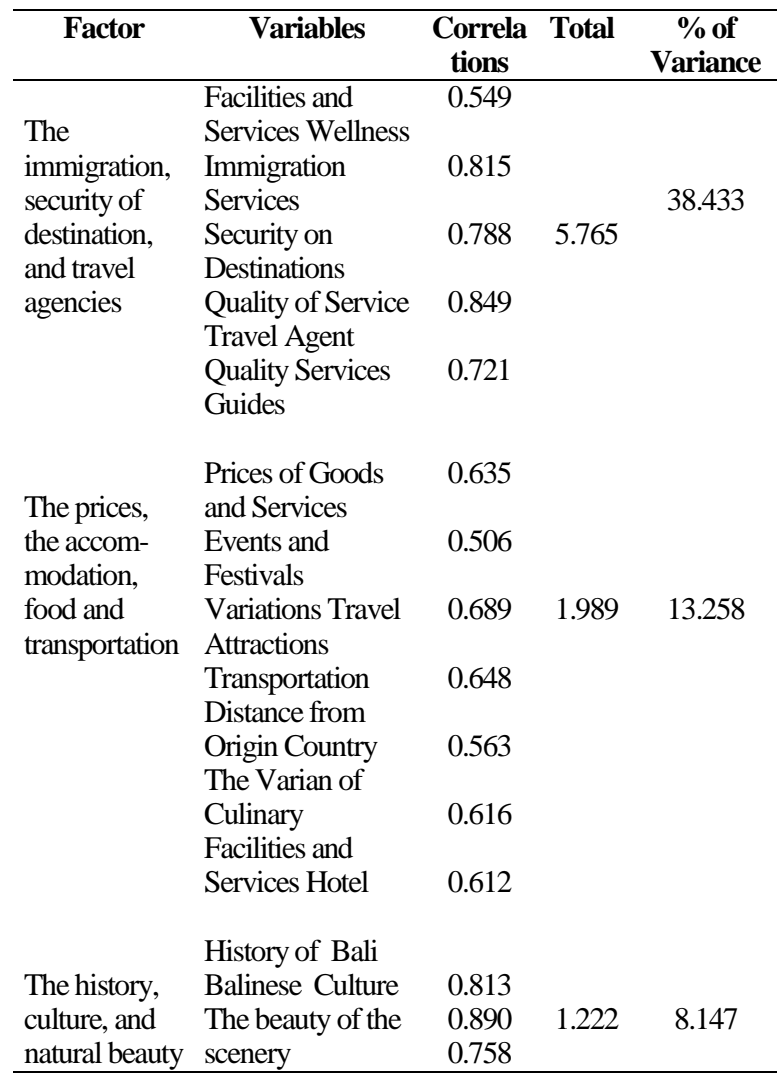


The dominant factors that determine the Europe tourists travelled to Bali can be explained as follows: The first factors that the most decisive European tourists coming to Bali are factors of immigration, security destinations, and travel agencies. The second factors that also determine European tourists travelled to Bali are the prices, accommodations, food and beverage, and transportation. While the last factors that determine the selection of European tourists traveling to Bali are factors of history, culture, and the beauty of the scenery.

\section{Predominantly Factors Determine European Tourist Travel to Bali}

The dominant factors that determine the Europe tourists travelled to Bali can be explained as follows: The first factors that the most decisive European tourists coming to Bali are factors of immigration, security destinations, and travel agencies. The second factors that also determine European tourists travelled to Bali are the prices, accommodations, food and beverage, and transportation. While the last factors that determine the selection of European tourists traveling to Bali are factors of history, culture, and the beauty of the scenery.

\section{Conclusion and Recommendations}

The factors as the main attraction of tourism Bali from perspective of Europe tourists are (1) the immigration, security of destinations, and travel agencies, (2) the prices, the accommodation, food and transport, (3) the history, culture, and natural beauty. While the most dominant factors in determining Europe tourists travelled to Bali are immigration, security destinations, and travel agencies.

Whatever development strategy in order to increase the number of tourist arrivals from Europe country can be done by improving the quality of immigration services, destination improved security, and improved quality of service travel agency that focus on Europe tourist. The next strategy is to maintain the stability of prices of goods and services, especially those related to the supply of tourism sector, maintaining the quality of accommodations, increasing the variety of culinary and arrangement of transportation services, especially related to transportation of tourists.

The factors of history, culture, and the beauty of the scenery are factors that need to be maintained. It is because of the strength point of Bali destination. It is corroborated by the finding of average of the three variables are in the highest rank by perception of Europe tourist.
The study's findings also indicate that the image of tourism Bali destinations as the destination's history, culture, and nature. These three variables are in accordance with expectations of Europe tourists who have been known as tourists who interest the historical destination, cultural tourism, and the beauty of the scenery. The implications of the research findings to destination promotional strategies is to highlight the power of destination with regard to the special interested in history, culture, and nature.

\section{References}

Chi, G. (2005). A study of developing destination loyalty model. Submitted dissertation, Faculty of the Graduate College of the Oklahoma State University in Partial Fulfillment of the Requirements for the Degree of Doctor of Philosophy.

Coban, S. (2012). The effects of the image of destination on tourist satisfaction and loyalty: The case of Cappadocia. European Journal of Social Sciences, 29(2), 222-232.

Esichaikul, R. (2012). Travel motivations, behavior and requirements of European senior tourists to Thailand. Sukhothai Thammathirat Open University, 10(2). 47-58.

Crompton. John L., Paul C. Fakeye, Chi-Chuan Lue. (1992). Image differences between prospective, first-time, and repeat visitors to the lower Rio Grande Valley. Journal of Travel Research, $30(2), 10-15$.

Gartner, W. C. (1993). Image formation process. Journal of Travel \& Tourism Marketing, 2(2/3), 191-216.

Goeldner, Charles R, Ritchie., J. R. Brent, \& McIntosh, Robert W. (1999). Tourism-principles, practices, philosophies. $8^{\text {th }}$ ed. Indianapolis, IN: John Wiley \& Sons.

Hair, J. F., Black, W. C. Babin, B. J., Anderson, R.. E., \& Tantham, R.. L. (2006). Multivariate Data Analysis ( $6^{\text {th }}$ ed). Upper Saddle River, NJ: PrenticeHall.

Jamaludin, M., Johari, S., Aziz, A., Kayat, K., \& Yusof, A. R. M. (2012) Examining structural relationship between destination image, tourist satisfaction and destination loyalty. International Journal of Independent Research and Studies IJIRS. ISSN: 2226-4817; EISSN: 2304- 6953, l(3), 89-96.

Keown, C., Jacobs, L., \& Worthley, R. (1984). American tourists' perceptions of retail stores in 12 selected countries. Journal of Travel Research, 22(3), 26-30. 
Mazursky, D. \& Jacoby, J. (1986) Exploring the development of store images. Journal of Retailing, Vol. 62, No. 2, 1986, pp. 145-165.

Milman, A. \& Pizam, A. (1995). The role of awareness and familiarity with a destination: The central Florida case. Journal of Travel Research, $33(3), 21-27$.
Santoso, S. (2005). Pengolahan statistik dengan SPSS. Yogyakarta: Penerbit Andi.

Sutika, I. K. (2016). Wisman asal Eropa ke Bali meningkat. Retrieved January 3, 2017, from http:// bali.antaranews.com/berita/89240/wisman-asal eropa-ke-bali-meningkat. 